\title{
LUPUS VULGARIS DENGAN LESI DISEMINATA
}

\author{
${ }^{1}$ Nana N. Jayadi \\ ${ }^{1}$ Niken Ernaningtyas \\ ${ }^{1}$ Nurdjannah J. Niode \\ ${ }^{2}$ Marthen C. P. Wongkar
}

\author{
${ }^{1}$ Departemen Ilmu Kesehatan Kulit dan Kelamin \\ ${ }^{2}$ Bagian Ilmu Penyakit Dalam \\ Fakultas Kedokteran Universitas Sam Ratulangi Manado \\ Email: novia_jayadi@yahoo.com
}

\begin{abstract}
Lupus vulgaris (LV) is a chronic progressive form of paucibacillary cutaneous tuberculosis. Lesion is usually solitary in the form of nodes or erythematous plaques with an apple-jelly sign on diascopy. Disseminated LV is a rare form of cutanoeus tuberculosis with multiple lesions in several body areas. We reported a male of 40 years old with a suppurative wound on the left neck and reddish nodules on the face, neck, trunk, and limbs along with fever, night sweats, weight loss, and history of previous TB infections. There were multiple erythematous nodules and painful suppurating ulcers with enlargement of several lymph nodes. Apple-jelly sign appeared on diascopy. The FNAB showed specific granulamatous inflammation for TB with lymphocytes, epitheloid macrophages, and multinucleated giant cells. The histopathological finding showed tubercles surrounded by macrophages and lymphocytes. Anti-tuberculosis drugs category I were given for 6 months, ofloxacin, and open wound care compressed with $\mathrm{NaCl} 0.9 \%$. In the third month of observation, there was significant improvement. Conclusion: This case was diagnosed as lupus vulgaris based on the history of lymphadenitis TB and scrofuloderma, lesions in several body area with positive diascopy test, the FNAB as well as the histopathologic result supporting the diagnosis of tuberculosis, and there was significant improvement after treatment with antiTB drugs.
\end{abstract}

Keywords: lupus vulgaris, diseminata, tuberculosis, ofloksasin

\begin{abstract}
Abstrak: Lupus vulgaris (LV) merupakan tuberkulosis (TB) kutis pausibasiler kronis dan progresif. Lesi biasanya soliter, berupa nodus atau plak eritematosa dengan gambaran applejelly pada diaskopi. Lupus vulgaris diseminata merupakan bentuk TB kutis yang jarang ditemukan dengan lesi multipel pada beberapa area tubuh secara bersamaan. Kami melaporkan seorang laki-laki, 40 tahun, dengan luka bernanah pada leher kiri dan benjolan-benjolan kemerahan pada wajah, leher, badan, dan tungkai disertai demam, keringat malam, penurunan berat badan dan riwayat infeksi tuberkulosis sebelumnya. Pada pemeriksaan fisik tampak nodus eritematosa multipel disertai ulkus bernanah dan pembesaran beberapa kelenjar getah bening. Gambaran apple-jelly tampak pada diaskopi. Pemeriksaan FNAB menunjukkan gambaran radang granulomatik spesifik TB dengan adanya sel-sel radang limfosit, kelompok makrofag epiteloid, dan sel-sel datia Langhans. Pemeriksaan histopatologis memberikan gambaran tuberkel yang dikelilingi oleh makrofag dan limfosit. Terapi diberikan berupa OAT kategori I selama 6 bulan, ofloksasin, dan kompres terbuka dengan NaCL 0,9\%. Pada bulan ketiga tampak perbaikan signifikan. Simpulan: Pada kasus ini, diagnosis lupus vulgaris ditegakkan berdasarkan adanya riwayat limfadenitis TB dan skrofuloderma, lesi di beberapa area tubuh sekaligus dengan pemeriksaan diaskopi positif, gambaran FNAB dan histopatologis menunjang diagnosis TB, dan pengobatan dengan OAT memberikan perbaikan bermakna.
\end{abstract}

Kata kunci: lupus vulgaris, diseminata, OAT, ofloksasin 
Tuberkulosis kutis, seperti halnya tuberkulosis paru yang disebabkan oleh Mycobacterium tuberculosis (M. tuberculosis) atau mikobakterium atipikal lainnya, masih merupakan masalah kesehatan terutama di negara berkembang. ${ }^{1}$ Berdasarkan data World Health Organization (WHO) tahun 2009, Indonesia berada di posisi ke-5 dengan jumlah penderita tuberkulosis (TB) sebesar 429 ribu orang. Dari total seluruh TB, 11.215 kasus merupakan kasus TB ekstra paru. $^{2}$ Di RS Cipto Mangunkusumo (RSCM), skrofuloderma merupakan bentuk yang paling sering ditemukan (84\%), disusul tuberkulosis kutis verukosa (13\%). Lupus vulgaris yang dahulunya tidak ditemukan ternyata sekarang terdeteksi meskipun sangat jarang. ${ }^{1}$ Hingga saat ini, belum pernah dilaporkan kejadian kasus lupus vulgaris di RSUP Prof Dr. R. D. Kandou Manado.

Lupus vulgaris (LV) merupakan bentuk TB kutis pausibasiler kronis dan progresif, ditemukan pada individu dengan imunitas sedang dan sensitivitas tinggi terhadap tuberkulin. Cara infeksi dapat melalui inokulasi langsung, serta penjalaran hematogen dan limfogen. ${ }^{3}$ Lesi LV biasanya soliter, namun dapat ditemukan pada 2 atau 3 tempat secara bersamaan berupa makula dan papul berwarna merah kecoklatan dengan konsistensi lunak. Pada pemeriksaan diaskopi tampak gambaran apple-jelly. Lesi kemudian mengalami perkembangan yang ditandai dengan peninggian lesi, pelebaran ke arah perifer, warna menjadi lebih kecoklatan, dan pembentukan plak; dapat pula terjadi erosi, ulserasi, serta jaringan parut.,

Lupus vulgaris diseminata adalah LV dengan lesi multipel, terdapat pada beberapa area tubuh secara bersamaan akibat penyebaran secara hematogen dari fokus tuberkulosis. ${ }^{3,4}$ Lesi LV diseminata, seperti halnya lesi LV yang khas, dapat dilihat dari gejala klinis dan adanya gambaran karakteristik apple-jelly. Pemeriksaan penunjang lainnya yaitu pemeriksaan histopatologi, kultur, dan polymerase chain reaction (PCR) ${ }^{1,3,4}$ Tes
Mantoux biasanya memberikan hasil positif kuat. ${ }^{3-5}$ Prinsip pengobatan pada umumnya sama dengan TB paru yaitu dengan pengobatan kombinasi obat anti tuberkulosis (OAT). ${ }^{1}$

\section{LAPORAN KASUS}

Seorang laki-laki berusia 40 tahun, suku Mongondow, datang ke Poliklinik Kulit dan Kelamin RSUP Prof. Dr. R. D. Kandou Manado dengan luka bernanah pada leher kiri dan benjolan-benjolan kemerahan pada wajah, leher, badan, dan tungkai. Kelainan ini dialami sejak 3 bulan yang lalu, diawali dengan timbulnya benjolan-benjolan sebesar biji jagung di leher kiri yang kemudian berwarna kemerahan, bergabung menjadi satu, sebagian berisi nanah dan pecah membentuk luka. Leher kiri bengkak, terasa keras bila ditekan dan nyeri. Keluhan ini juga disertai demam, keringat malam, dan penurunan berat badan. Dua bulan kemudian, muncul benjolan-benjolan sewarna kulit lain yang tersebar di pipi kanan, leher kanan, dada, perut, punggung, dan kedua selangkangan. Pasien memiliki riwayat limfadenitis TB dan skrofuloderma yang telah sembuh 3 tahun lalu. Riwayat batuk-batuk lama dan trauma pada leher tidak ditemukan; riwayat pemakaian obat tidak diketahui; dan pasien sudah mendapat vaksinasi BCG sebelumnya.

Pada pemeriksaan fisik didapatkan keadaan umum baik, berat badan $65 \mathrm{~kg}$, kesadaran kompos mentis, tekanan darah $110 / 70 \mathrm{mmHg}$, frekuensi nadi $82 \mathrm{x} /$ menit, frekuensi nafas $18 \mathrm{x} /$ menit dan suhu $36,7^{\circ} \mathrm{C}$. Ditemukan pembesaran kelenjar getah bening (KGB) submandibular dekstra dan sinistra, servikalis dekstra dan sinistra, aksilaris dekstra dan sinistra, inguinal dekstra dan sinistra, berdiameter $\pm 1-2 \mathrm{~cm}$, konsistensi lunak, mobilitas (-), nyeri tekan (-), dengan kulit diatasnya tampak normal. Hasil pemeriksaan jantung dan paru dalam batas normal serta tidak dijumpai pembesaran hati dan limpa.

Pada pemeriksaan dermatologis regio perioralis dekstra tampak nodus 
eritematosa, soliter, disertai ulkus dangkal di bagian tengah dengan diameter $\pm 0,5 \mathrm{~cm}$ disertai krusta kekuningan dan pus (Gambar 1A). Pada regio mandibularis dekstra, periaurikularis dekstra, torakalis anterior et posterior, abdominalis, brakialis, antebrakialis dekstra sinistra, inguinalis dekstra dan sinistra ditemukan papul dan nodus eritematosa dan sewarna kulit yang multipel (Gambar 1B). Tampak skar atrofik pada regio koli anterior bagian superior (Gambar 1C). Pada regio aurikularis, periaurikularis sinistra, koli sinistra, supraklavikularis sinistra ditemukan edema dan nodus eritematosa multipel, pustul multipel, ulkus multipel dengan ukuran bervariasi sekitar $0,5 \times 0,5 \times 0,2 \mathrm{~cm}$ hingga $5 \mathrm{x}$ $5 \times 0,2 \mathrm{~cm}$, tepi tidak teratur, dasar sebagian jaringan granulasi dan sebagian tertutup pus disertai krusta kekuningan, serta tidak tampak adanya fistel (Gambar 1D). Pemeriksaan diaskopi pada lesi menunjukkan apple jelly sign.

Pemeriksaan pus dengan pewarnaan Ziehl Nielsen menunjukkan adanya sel PMN namun tidak ditemukan adanya basil tahan asam (BTA). Pada pemeriksaan pus dengan pewarnaan Gram tampak adanya sel-sel PMN disertai kokus Gram positif dan negatif.

Diagnosis banding pada pasien ini ialah lupus vulgaris, skrofuloderma, mineralisasi kutan, misetoma, dan limfoma sehingga direncanakan beberapa pemeriksaan penunjang lain berupa pemeriksaan hematologi rutin, laju endap darah, sediaan apus darah tepi, kimia darah, fungsi hati, fungsi ginjal, laktat dehidrogenase, kalsium, fosfat, elektrolit, urinalisis, feses lengkap, kultur pus dan sensitivitas, foto toraks, tes Mantoux, biopsi kulit, kultur jamur, dan fine needle aspiration biopsy (FNAB) untuk menegakkan diagnosis pasti.

Dari hasil pemeriksaan laboratorium didapatkan kadar $\mathrm{Hb}$ yang menurun (10,6 /DL), peningkatan LED (101,4 mm/jam), dan penurunan glukosa darah puasa (GDP $61 \mathrm{mg} / \mathrm{dL}$ ). Fungsi hati, fungsi ginjal, urinalisis, dan pemeriksaan feses dalam batas normal. Kadar asam urat dalam batas normal, sedangkan kadar kalsium, fosfat dan laktat dehidrogenase menurun ringan. Tidak tampak adanya pertumbuhan jamur pada kultur jaringan. Pada kultur pus didapatkan adanya pertumbuhan kuman Staphylococcus aureus yang sensitif terhadap amikasin dan fosfomisin serta kuman Serratia marcescens yang sensitif terhadap amikasin, ampisilin sulbaktam, dan meropenem. Gambaran jantung dan paru pada foto toraks dalam batas normal.

Hasil pemeriksaan FNAB pada leher kiri menunjukkan adanya sel-sel radang limfosit, kelompok makrofag epiteloid, dan sel-sel datia Langhans. Pada pemeriksaan histopatologik dari nodus pada punggung tampak epidermis yang berulkus. Pada dermis di bawahnya tampak struktur granuloma atau tuberkel dengan nekrosis sentral dan bagian tepi terdiri dari sel-sel makrofag epiteloid, makrofag berbuih, dan limfosit. Kesan dari pemeriksaan histopatologik ialah radang granulomatik spesifik dengan infeksi sekunder. Gambaran histopatologik ini sesuai dengan lupus vulgaris.

Berdasarkan anamnesis, pemeriksaan fisik dan pemeriksaan penunjang, diagnosis kerja pada pasien ini ialah lupus vulgaris (diseminata) dan limfadenitis TB. Pasien kemudian dikonsulkan dan dirawat bersama dengan Bagian Penyakit Dalam.

Terapi awal yang diberikan berupa doksisiklin 2x100 mg, asam mefenamat $3 \times 500 \mathrm{mg}$, paracetamol 3 x $500 \mathrm{mg}$ bila demam, dan kompres terbuka dengan $\mathrm{NaCl}$ 0,9\% 3x30 menit. Setelah diagnosis lupus vulgaris diseminata dan limfadenitis TB ditegakkan diberikan terapi OAT berupa fixed dose combination (FDC) $1 \times 4$ tablet yang terdiri dari rifampisin (R) 10 $\mathrm{mg} / \mathrm{kgBB} / \mathrm{hari}$, isoniazid (H) $5 \mathrm{mg} / \mathrm{kgBB} /$ hari, pirazinamid $25 \mathrm{mg} / \mathrm{kgBB} / \mathrm{hari}$, dan etambutol (E) $15 \mathrm{mg} / \mathrm{kgBB}$ setiap hari selama 2 bulan dan kompres terbuka dengan $\mathrm{NaCl}$ 0.9\% 3x30 menit.

Pada kunjungan ulang (pengamatan hari ke-50 pengobatan), bengkak pada leher kiri pasien berkurang namun luka meluas dan pus bertambah karena sebagian nodus telah pecah (Gambar 2A). Nodus pada sudut kanan bibir membesar dengan luka 
yang melebar (Gambar 2B). Nodus eritema sewarna kulit pada badan dan ekstremitas sebagian telah mendatar, pecah dan menimbulkan luka. Pada pemeriksaan Gram dari pus pada luka didapatkan adanya sel-sel PMN serta kuman Gram positif dan negatif. Pasien mengeluh adanya bengkak dan nyeri pada sendi jari-jari tangan setelah minum OAT.

Pasien kemudian dikonsulkan ke Bagian Penyakit Dalam dan akan dilakukan pemeriksaan Voluntary Counseling and Testing (VCT), darah lengkap (DL), laju endap darah (LED), fungsi hati, fungsi ginjal, asam urat, dan FNAB pada nodul di atas bibir. Dari pemeriksaan laboratorium diperoleh hasil kadar $\mathrm{Hb}$ masih di bawah normal, LED yang menurun dibanding pemeriksaan sebelumnya (dari 101,4 $\mathrm{mm} / \mathrm{jam}$ menjadi $49 \mathrm{~mm} / \mathrm{jam})$, dan peningkatan kadar asam urat $(15,0 \mathrm{mg} / \mathrm{dL})$. Pemeriksaan VCT pada pasien menunjukkan hasil non-reaktif, dan tidak ditemukan tanda-tanda keganasan pada pemeriksaan FNAB. Terapi yang diberikan berupa pemberian sisipan HRZE selama 1 bulan, alopurinol 1x100 mg, ofloksasin 2 x 400 mg dan kompres terbuka dengan $\mathrm{NaCl}$ 0,9\% 3x30 menit.

Pada pengobatan hari ke-80 pasien kembali kontrol dan tampak perbaikan bermakna, dimana ulkus pada leher kiri mengering, pus berkurang, dan edema minimal (Gambar 3A). Nodus eritema pada area tubuh lain telah mendatar dengan ulkus yang sebagian juga telah kering (Gambar 3B). Terapi yang diberikan berupa OAT fase lanjutan dengan RH 3 x seminggu (rencana selama 4 bulan), ofloksasin 2 x $400 \mathrm{mg}$, dan kompres terbuka dengan $\mathrm{NaCl}$ 0.9\% 3x30 menit.

\section{BAHASAN}

Istilah lupus vulgaris (LV) pertama kali dikemukakan oleh Erasmus Wilson pada tahun $1865 .{ }^{6}$ Lupus vulgaris adalah salah satu bentuk TB kutis yang kronik, progresif, ditemukan pada individu dengan imunitas sedang, memiliki sensitivitas yang tinggi terhadap tuberkulin dan merupakan reinfeksi tuberkulosis kutis sebelumnya dengan penjalaran secara hematogen, limfogen, maupun penjalaran langsung setelah terjadi inokulasi. ${ }^{4,7,8}$ Lupus vulgaris diseminata merupakan bentuk LV dengan lesi multipel atau terdapat di beberapa area tubuh secara bersamaan sebagai konsekuensi penjalaran hematogen dari fokus tuberkulosis. Bentuk LV diseminata ini biasanya ditemukan pada individu dengan TB paru aktif atau timbul beberapa lama setelah terjadi gangguan imunitas, misalnya akibat terkena campak. ${ }^{3,4}$ Sebagaimana halnya dengan TB paru, maka LV sebagai salah satu TB kutis juga merupakan masalah kesehatan di negara berkembang seperti Indonesia. Bentuk LV jarang dijumpai pada negara tropis, lebih sering dijumpai pada wanita, dan dapat mengenai semua umur. ${ }^{3}$

Lupus vulgaris sebagai bagian dari TB memiliki gejala lokal dan gejala sistemik. Gejala lokal yang timbul sesuai dengan organ yang terlibat. Gejala sistemik dapat berupa demam, malaise, keringat malam, anoreksia dan berat badan menurun. ${ }^{10}$ Gambaran klinis LV berupa nodus atau plak eritematosa yang berubah warna menjadi kuning pada diaskopi (apple-jelly sign). Nodi tersebut dalam perkembangannya dapat berkonfluensi menjadi plak yang bersifat dekstruktif dan diikuti dengan ulserasi. ${ }^{1,9}$ Sekitar 90\% lesi LV terdapat pada wajah dan leher. Biasanya lesi timbul di hidung, pipi, daun telinga atau kulit kepala dan perlahan meluas ke area yang lain. ${ }^{3}$

Pasien seorang laki-laki berusia 40 tahun dengan benjolan-benjolan kemerahan disertai luka bernanah pada leher kiri yang terkadang terasa nyeri sejak 1 bulan. Awalnya, benjolan-benjolan yang timbul sewarna kulit dan berukuran sebesar biji jagung, sebagian kemudian bergabung menjadi satu, berwarna kemerahan, bernanah dan pecah menimbulkan luka. Beberapa minggu kemudian timbul benjolan-benjolan lain yang tersebar di pipi kanan, leher, dada, perut, punggung dan kedua selangkangan. 

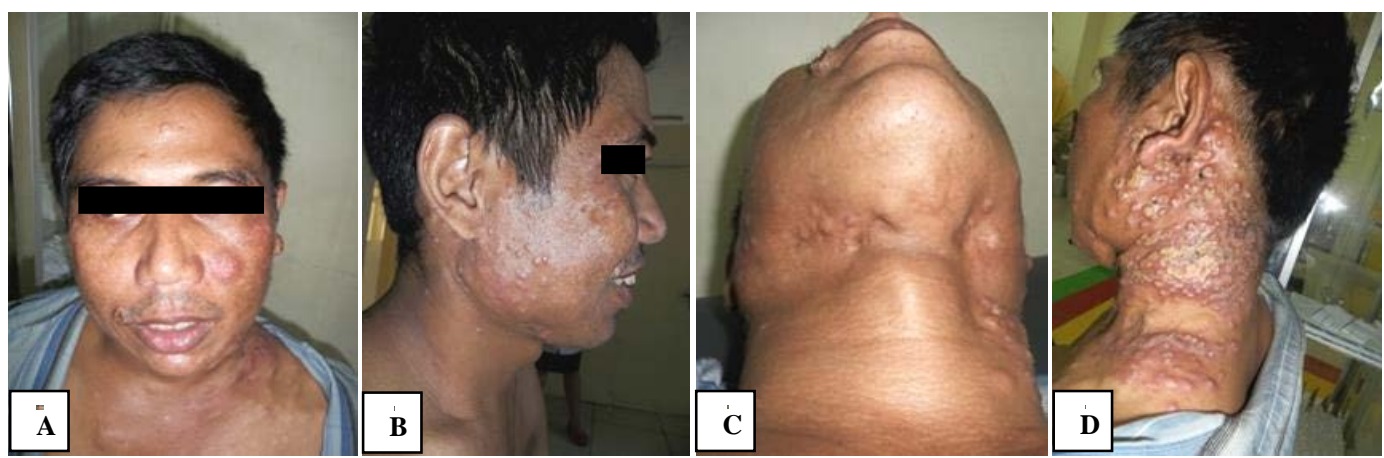

Gambar 1. Pengamatan saat pertama kali pasien datang berobat. A, nodus eritematosa, soliter, disertai ulkus dangkal di bagian tengah dengan diameter $\pm 0,5 \mathrm{~cm}$ disertai krusta kekuningan dan pus pada regio perioralis dekstra. B, papul dan nodus eritematosa dan sewarna kulit yang multipel pada regio mandibularis dekstra dan periaurikularis dekstra. C, skar atrofik pada regio koli anterior bagian superior. D, edema dan nodus eritematosa multipel, pustul multipel, ulkus multipel pada regio aurikularis, periaurikularis sinistra, koli sinistra, dan supraklaviularis sinistra
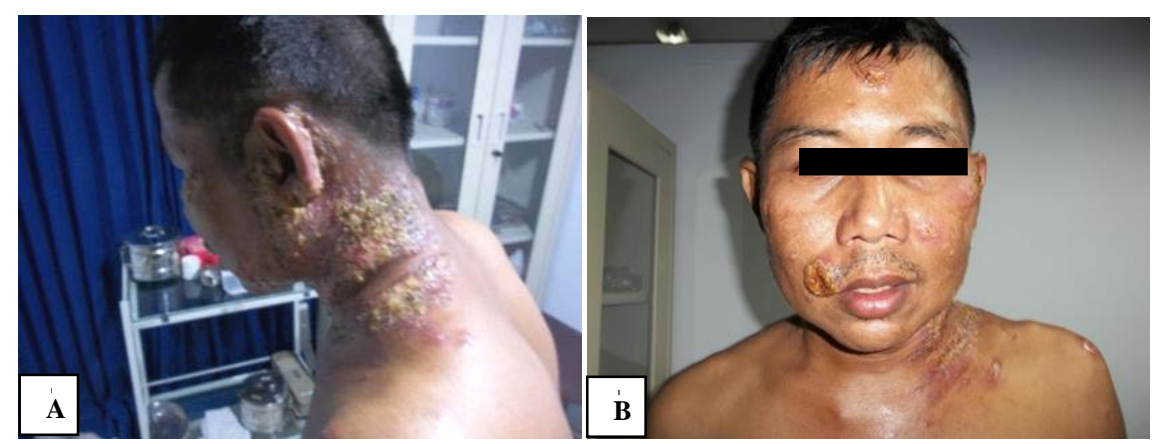

Gambar 2. Pengamatan hari ke-50 pengobatan. A, bengkak pada leher kiri berkurang namun luka meluas dan pus bertambah karena sebagian nodi telah pecah. B, nodus pada sudut kanan bibir membesar dengan luka yang melebar. Nodi eritema sewarna kulit pada badan dan ekstremitas sebagian telah mendatar, pecah dan menimbulkan luka

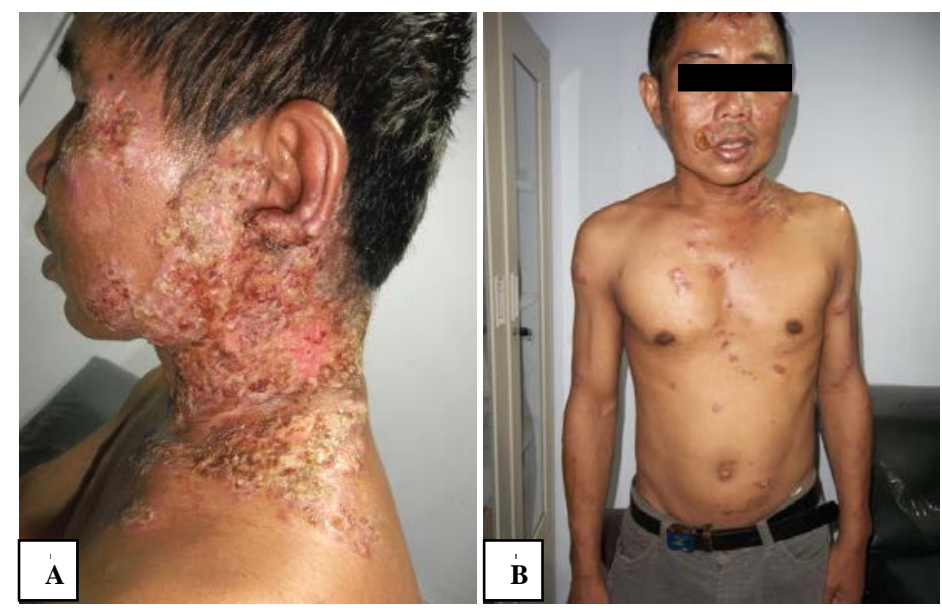

Gambar 3. Pengamatan hari ke-80 pengobatan. A, ulkus pada leher kiri mengering, pus berkurang, dan edema minimal. B, nodi eritema pada area tubuh lain telah mendatar dengan ulkus yang sebagian juga telah kering 
Gejala sistemik yang dialami berupa demam, keringat malam dan penurunan berat badan sebanyak $6 \mathrm{~kg}$ dalam 1 bulan terakhir. Riwayat batuk berdahak, riwayat trauma pada leher kiri dan riwayat asam urat disangkal. Pasien memiliki riwayat limfadenitis TB disertai skrofuloderma pada tahun 2011. Pengobatan dengan OAT TB dijalankan pasien secara teratur dan pasien telah dinyatakan sembuh.

Menurut acuan pustaka, lesi LV pada daerah kepala dan leher biasanya berhubungan dengan limfangitis dan limfadenitis. ${ }^{5}$ Pembesaran KGB pada kasus ini ditemukan pada KGB submandibula dekstra dan sinistra, servikalis dekstra dan sinistra, dan inguinal dekstra dan sinistra dengan diameter $\pm 1-2 \mathrm{~cm}$, konsistensi lunak, mobilitas (-), nyeri tekan (-), tanpa disertai tanda-tanda radang pada kulit diatasnya.

Lesi LV biasanya timbul sebagai lesi soliter di atas kulit normal, namun lesi dapat juga ditemukan pada daerah inokulasi primer pada pembuatan tato, pada skar skrofuloderma, atau di tempat injeksi BCG. Lesi yang multipel atau bentuk diseminata dapat ditemukan pada pasien dengan TB paru aktif.,4 Gambaran klinis LV dapat dibagi menjadi lima bentuk tergantung pada respon jaringan lokal terhadap infeksi, yaitu: plak, ulserasi dan mutilasi, vegetasi, tumor, dan papulonodular. Bentuk atipikal juga semakin sering ditemukan. ${ }^{4}$ Mukosa dapat pula terlibat, ditandai adanya papul, ulkus, atau massa granuloma. ${ }^{3}$ Pada kasus ini, ditemukan limfadenitis TB disertai lesi kulit berupa kombinasi bentuk ulserasi pada leher dan bentuk papulonodular yang tampak tersebar di wajah, leher, badan, dan ekstremitas tetapi tidak ditemukan lesi pada mukosa. Pada sudut bibir kiri tampak nodus eritematosa soliter disertai ulkus dangkal di bagian tengah dengan permukaan tertutup krusta kekuningan. Leher kiri, daerah di sekitar telinga, dan daun telinga kiri tampak edema dan eritema disertai nodus eritematosa, pustul, serta ulkus dangkal multipel yang sebagian tertutup pus dan krusta kekuningan. Tidak tampak adanya fistel seperti yang sering dijumpai pada skrofuloderma. Pada pemeriksaan diaskopi, kelompok nodus eritema tersebut berubah warna menjadi kuning yang menandakan apple-jelly sign positif. Skar atrofik akibat lesi skrofuloderma sebelumnya ditemukan pada daerah submandibularis. Nodus eritematosa dan sewarna kulit juga tersebar pada pipi kanan, di sekitar telinga kanan, dada, perut, punggung, serta kedua lengan dan paha.

Berdasarkan anamnesis dan pemeriksaan fisik, kasus ini pada awalnya memiliki beberapa diagnosis banding yaitu: lupus vulgaris, skrofuloderma, misetoma, mineralisasi kutan, dan limfoma. Dengan terdapatnya beberapa gejala sistemik TB, pembesaran KGB leher, riwayat limfadenitis TB, dan riwayat skrofuloderma sebelumnya maka LV dan skrofuloderma merupakan diagnosis banding. Pasien juga bekerja sebagai petani jagung dan berisiko tertusuk atau tergores tanaman sehingga risiko infeksi seperti misetoma cukup tinggi meski disangkal oleh pasien. Limfadenopati disertai nodus eritema generalisata dapat ditemukan pada limfoma, sedangkan nodus sewarna kulit dapat dijumpai pada mineralisasi kutan.

Pemeriksaan diaskopi pada lesi memberikan gambaran apple-jelly yang merupakan karakteristik lesi LV, meski tidak selalu dapat ditemukan. Pada pemeriksaan laboratorium sederhana dengan sediaan berupa pus dari ulkus di leher pemeriksaan Ziehl Nielsen dan pemeriksaan Gram dengan hasil pemeriksaan tidak ditemukan basil tahan asam (BTA) dengan pewarnaan Ziehl Nielsen dan adanya sel PMN, kokus Gram positif dan negatif dengan Pemeriksaan Gram. LV merupakan bentuk TB kutis pausibasiler sehingga BTA pada pewarnaan Ziehl Nielsen dan kultur seringkali memberikan hasil negatif. ${ }^{4}$ Diperlukan beberapa pemeriksaan penunjang lain untuk menyingkirkan diagnosis banding berupa pemeriksaan pemeriksaan hematologi rutin, LED, sediaan apus darah tepi, kimia darah, fungsi hati, fungsi ginjal, laktat dehidrogenase, kalsium, fosfat, elektrolit, urinalisis, feses lengkap, kultur pus dan 
sensitivitas, foto toraks, tes Mantoux, biopsi kulit, kultur jamur, dan FNAB. Dari hasil pemeriksaan laboratorium didapatkan kadar $\mathrm{Hb}$ yang menurun (10,6/dL), peningkatan LED (101,4 $\mathrm{mm} / \mathrm{jam})$, penurunan GDP (61 mg/dL), fungsi hati, fungsi ginjal, urinalisa dan feses dalam batas normal. Kadar asam urat dalam batas normal, kadar kalsium, fosfat dan laktat dehidrogenase menurun ringan serta tidak tampak adanya pertumbuhan jamur pada kultur jaringan sehingga diagnosis banding mineralisasi kutan, limfoma, dan aktinomisetoma dapat disingkirkan.

Pemeriksaan foto toraks diperlukan pada kasus TB kutis karena paru merupakan port d'entree lebih dari 98\% kasus infeksi TB. ${ }^{10} \mathrm{LV}$ diseminata dengan lesi yang multipel juga seringkali berhubungan dengan TB paru aktif. ${ }^{3,4}$ Standar diagnosis TB kutis ialah pemeriksaan mikroskopik, kultur, dan pemeriksaan histopatologi dari spesimen kulit. Tes Mantoux dan PCR juga dapat digunakan sebagai penunjang diagnosis. ${ }^{1}$

Pada kasus ini gambaran jantung dan paru pasien dalam batas normal. Kuman BTA pada sediaan pus dengan pewarnaan Ziehl Nielsen juga tidak ditemukan karena LV merupakan TB kutis pausibasiler yang berbeda dengan skrofuloderma yang biasanya multibasiler.

Tes Mantoux atau uji tuberkulin adalah tes dengan menggunakan komponen protein kuman TB yang mempunyai sifat antigenik kuat. Jika disuntikkan secara intrakutan pada seseorang yang telah terinfeksi TB maka akan terjadi reaksi berupa indurasi di lokasi suntikan. ${ }^{12}$ Hingga saat ini, uji tuberkulin masih mempunyai nilai diagnostik yang tinggi terutama pada anak, namun kurang berarti pada dewasa atau pada seseorang yang sebelumnya pernah memiliki riwayat TB. ${ }^{10,12}$ Pada kasus ini pasien sudah memiliki riwayat limfadenitis TB dan skrofuloderma sebelumnya sehingga tidak dilakukan uji tuberkulin karena meski hasilnya positif menjadi kurang bermakna.

Lupus vulgaris memiliki gambaran histopatologi yang bervariasi. Gambaran khas berupa ditemukannya tuberkeltuberkel yang sebagian menyatu, dengan atau tanpa nekrosis kaseosa, dikelilingi oleh sel epiteloid dan sel datia Langhans pada dermis. Limfosit di sekeliling tuberkel tampak jelas. Bakteri biasanya jarang ditemukan. Ulserasi, atrofi atau akantosis dapat ditemukan pada epidermis diatasnya. ${ }^{13,14}$ Gambaran histopatologi skrofuloderma pada dermis berupa pembentukan abses disertai ulserasi. Tuberkel dan nekrosis kaseosa dapat ditemukan di perifer dengan bakteri dalam jumlah banyak. ${ }^{4,13}$ Pemeriksaan histopatologi pada kasus ini berasal dari nodul pada punggung dan memiliki gambaran histopatologi sesuai dengan gambaran lupus vulgaris. Dari pemeriksaan tersebut tampak epidermis yang berulkus. Pada dermis di bawahnya tampak struktur granuloma atau tuberkel dengan sentral nekrosis dan bagian tepi terdiri dari sel-sel makrofag epiteloid, makrofag berbuih, dan limfosit. Kesan dari pemeriksaan histopatologi ialah radang granulomatik spesifik dengan infeksi sekunder (menyokong suatu lupus vulgaris).

Pemeriksaan FNAB leher kiri juga dilakukan pada kasus ini dengan hasil yang juga sesuai dengan gambaran TB berupa ditemukannya sel-sel radang limfosit, kelompok makrofag epiteloid, dan sel-sel datia. Pemeriksaan penunjang lain yang dapat dilakukan untuk menegakkan diagnosis TB kutis ialah dengan ditemukannya $M$. tuberculosis pada kultur dan polymerase chain reaction (PCR) namun pada kasus ini kedua pemeriksaan tersebut tidak dilakukan karena media kultur dan PCR tidak tersedia.

Diagnosis lupus vulgaris diseminata pada kasus ini ditegakkan berdasarkan adanya riwayat infeksi TB sebelumnya, gejala sistemik TB seperti demam, keringat malam dan berat badan menurun disertai gejala lokal LV berupa timbulnya nodusnodus eritema dan sewarna kulit multipel pada beberapa area tubuh secara bersamaan, nodi di leher sebagian pecah dan mengalami ulserasi tanpa disertai adanya fistel. Pemeriksaan diaskopi pada 
lesi memberikan gambaran apple-jelly yang merupakan karakteristik LV. Pemeriksaan FNAB pada leher dan histopatologi pada lesi di punggung sesuai dengan gambaran LV sehingga diagnosis lupus vulgaris diseminata pada kasus ini dapat ditegakkan. Namun, penyebab terjadinya penyebaran hematogen belum diketahui pasti karena tidak ditemukan adanya TB paru dan riwayat adanya penyakit tertentu yang dapat menyebabkan menurunnya imunitas sebelum timbulnya lesi disangkal oleh pasien.

Terapi awal yang diberikan sebelum diagnosis pasti lupus vulgaris diseminata ditegakkan berupa doksisiklin 2x100 mg, asam mefenamat 3x500 mg, parasetamol 3 x 500 mg bila demam, dan kompres terbuka dengan $\mathrm{NaCl}$ 0.9\% 3x30 menit. Berdasarkan International Standard for Tuberculosis Care (ISTC), terapi antibiotik awal pada pasien yang dicurigai TB sebaiknya tidak menggunakan golongan kuinolon karena golongan kuinolon merupakan obat TB lini kedua yang digunakan pada kasus TB resisten OAT ${ }^{9}$ dan TB kutis (lupus vulgaris dan skrofuloderma) merupakan salah satu diagnosis banding pada kasus ini sehingga penggunaan antibiotik golongan kuinolon dihindari. Pada pemeriksaan Gram dari pus ditemukan kokus Gram positif dan negatif dan diberikan doksisiklin untuk mengatasi kemungkinan adanya infeksi sekunder pada luka. Doksisiklin merupakan golongan tetrasiklin yang merupakan antibiotik dengan sifat bakteriostatik. Golongan ini memiliki spektrum antibakteri luas yang meliputi kuman Gram positif dan negatif serta aerobik dan anaerobik. ${ }^{11}$ Terapi simtomatis berupa analgetik asam mefenamat dan antipiretik parasetamol diberikan karena pasien mengeluh nyeri pada leher kiri dan demam. Kompres terbuka dengan $\mathrm{NaCl}$ 0,9\% 3x30 menit bertujuan untuk mengangkat pus dan krusta sehingga luka bersih dan penyembuhannya lebih baik.

Pengobatan TB pada pasien ini dimulai setelah diagnosis lupus vugaris diseminata dapat ditegakkan. Prinsip pengobatan TB kulit pada prinsipnya sama dengan TB pada organ lain yaitu dengan OAT. Pengobatan TB dibagi menjadi dua tahap yaitu tahap awal (intensif) dan lanjutan. Pada umumnya, lama pengobatan 6-8 bulan. Pada tahap awal diberikan kombinasi 4 macam obat yaitu rifampisin (R) 10 $\mathrm{mg} / \mathrm{kgBB} / \mathrm{hari}$, isoniazid (H) $5 \mathrm{mg} / \mathrm{kgBB} /$ hari, pirazinamid $25 \mathrm{mg} / \mathrm{kgBB} / \mathrm{hari}$, dan etambutol (E) $15 \mathrm{mg} / \mathrm{kgBB}$ setiap hari selama dua bulan. OAT tahap lanjutan yang diberikan ialah rifampisin dan isoniazid 3 kali perminggu selama 4 bulan. ${ }^{10}$ Dalam kasus ini, terapi yang diberikan kepada pasien adalah FDC 1 x 4 tablet selama dua bulan dan vitamin B6 1x1 tablet. Pasien dianjurkan kontrol dua bulan kemudian.

Setelah 2 bulan menjalani pengobatan tahap intensif, bengkak pada leher kiri pasien berkurang namun luka meluas dan nanah bertambah karena sebagian nodus telah pecah. Nodus pada sudut kanan bibir membesar dengan luka yang melebar. Nodus eritematosa sewarna kulit pada badan dan ekstremitas sebagian telah mendatar, pecah dan menimbulkan luka. Pada pemeriksaan Gram dari pus pada luka didapatkan adanya sel-sel PMN serta kuman Gram positif dan negatif. Pasien mengeluh adanya bengkak dan nyeri pada sendi jari-jari tangan setelah minum OAT. Pasien kemudian dikonsulkan ke Poliklinik Penyakit Dalam untuk evaluasi lebih lanjut dan dianjurkan untuk melakukan pemeriksaan VCT, DL, LED, fungsi hati, fungsi ginjal, asam urat, dan FNAB pada nodul diatas bibir. Pemeriksaan FNAB pada nodul diatas bibir perlu dilakukan untuk melihat apakah terdapat tanda-tanda keganasan karena lesi LV dapat berkembang menjadi suatu karsinoma terutama karsinoma sel skuamosa. ${ }^{3}$ Dari pemeriksaan laboratorium diperoleh peningkatan kadar asam urat $(15,0 \mathrm{mg} / \mathrm{dL})$ yang diduga disebabkan oleh pirazinamid yang memiliki efek samping berupa hiperurisemia dan nyeri sendi. ${ }^{10}$ Pemeriksaan VCT pada pasien memberikan hasil non reaktif dan tidak tampak tanda-tanda keganasan pada pemeriksaan FNAB.

Terapi tambahan yang diberikan 
berupa alopurinol 1 x $100 \mathrm{mg}$, ofloksasin 2 x $400 \mathrm{mg}$, dan rencana pemberian sisipan HRZE selama 1 bulan. Perbaikan klinis yang minimal setelah menyelesaikan tahap inisial selama dua bulan menimbulkan dugaan adanya resistensi terhadap OAT yang menjadi dasar pertimbangan pemberian ofloksasin 2 x $400 \mathrm{mg}$ dan sisipan HRZE pada pasien ini meskipun hasil kultur pus resisten terhadap ofloksasin. Menurut acuan pustaka, diduga terjadi resistensi obat bila setelah fase inisial selesai tidak terlihat adanya respon pengobatan secara klinis, pasien gagal pengobatan atau putus obat, dan kasus kambuh setelah pengobatan.,15 Ofloksasin merupakan golongan florokuinolon yang mempunyai daya antibakteri kuat terhadap kuman Gram negatif dan lebih lemah terhadap kuman Gram positif. Ofloksasin memiliki efek bakterisid ringan terhadap mikobakterium sehingga dapat digunakan sebagai terapi TB lini kedua. ${ }^{15-17}$

Pada pengobatan hari ke-80 tampak perbaikan bermakna dimana luka pada leher kiri mengering, nanah berkurang, dan bengkak minimal. Nodus eritema pada area tubuh lain telah mendatar dengan luka yang juga telah mengering. Pasien kembali dikonsulkan ke Poliklinik Penyakit Dalam dan terapi OAT fase lanjutan, ofloksasin 2 x 400 mg dan kompres terbuka dengan $\mathrm{NaCl}$ 0,9\% 3x30 menit dilanjutkan.

\section{SIMPULAN}

Telah dilaporkan satu kasus lupus vulgaris diseminata pada seorang laki-laki berusia 40 tahun dengan gejala demam, keringat malam, dan penurunan berat badan disertai lesi berupa nodus eritematosa yang sebagian mengalami ulserasi pada beberapa area tubuh secara bersamaan seperti wajah, leher badan serta kedua lengan dan paha disertai gambaran apple-jelly pada pemeriksaan diaskopi. Pada pemeriksaan laboratorium pasien didapatkan peningkatan LED yang biasanya ditemukan pada TB. Diagnosis akhir lupus vulgaris diseminata pada pasien ini ditegakkan melalui pemeriksaan FNAB dan histo- patologik yang memberikan gambaran khas LV. Terapi OAT yang diberikan terbagi atas 3 fase, yaitu fase inisial HRZE selama 2 bulan, dilanjutkan dengan sisipan HRZE selama 1 bulan dan fase lanjutan HR yang rencana diberikan selama 4 bulan. Pengobatan lain berupa ofloksasin 2x400

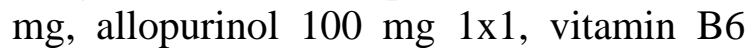
$1 \mathrm{x} 1$ dan kompres luka dengan $\mathrm{NaCl}$ 0.9\% 3x30 menit juga diberikan. Respon yang baik terhadap terapi tampak pada bulan ketiga pengobatan.

\section{DAFTAR PUSTAKA}

1. Djuanda A. Tuberkulosis Kutis. In: Djuanda A, Hamzah M, Aisah S, editors. Ilmu Penyakit Kulit dan Kelamin (5th ed.). Jakarta: Fakultas Kedokteran Universitas Indonesia, 2007; p. 64-72.

2. Perkumpulan Pemberantasan Tuberkulosis Kutis di Indonesia (PPTI). TB di Indonesia peringkat keempat. 2011. [cited 2014 May 8]. Available from: www.ppti.info/2012/09/tbc-diindonesia-peringkat-ke-5.html.

3. Sethi A. Tuberculosis and infection with atypical mycobacteria. In: Goldsmith LA, Katz LI, Gilchrest BA, Paleer AS, Leffel DJ, Wolff K, editors. Fitzpatrick's Dermatology in General Medicine (8th ed.). New York: McGraw Hill, 2008; p. 2225-40.

4. Yates VM. Mycobacterial infection. In: Burns T, Breatnach SM, Cox N, Griffith C, editors. Rook's Textbook of Dermatology (8th ed.). London: Blackwell publishing Ltd, 2010; p.6737.

5. James WD, Berger TG, Elston DM. Andrew's Diseases of the skin clinical dermatology (11th ed.). Philadephia: Elsevier, 2015; p. 323-33.

6. Padmavathy L, Rao LL, Pari T, Ethirajan N, Krishnaswamy B. Lupus vulgaris and tuberculosis verrucosa cutis (TBVC) a clinical, pathological and epidemiological study of 71 cases. Indian J Tuberc. 2008;55:203-9.

7. Pusponegoro EHD. Tatalaksana tuberkulosis kutis. World TB Day 2012. Jakarta, 14 Mei 2012.

8. Rahman MH, Ansari NP, Hadiuzzman MD, Nipa NI, Islam S, Mumu SA, et 
al. Lupus vulgaris on the buttock mimicking tinea corporis. Journal of Pakistan Association of Dermatologists. 2011;21(4):295-7.

9. Tim kelompok kerja tuberkulosis. Tuberkulosis: pedoman diagnosis dan penatalaksanaan di Indonesia. Jakarta: Perhimpunan Dokter Paru Indonesia, 2011.

10. Shimizu H. Mycobacterial infections. 2013. [cited 2014 May 8]. Available from: http://www.derm-hokudai.jp/shimizudermatology/pdf/26-01.pdf.

11. Setiabudy R. Golongan tetrasiklin dan kloramfenikol. In: Gunawan SG, Setiabudy R, Nafrialdy, Elysabeth, editors. Farmakologi dan Terapi. Jakarta: Departemen Farmakologi dan Terapeutik Fakultas Kedokteran Universitas Indonesia, 2007; p. 694-703.

12. Rahajoe N, Basir D, Makmuri MS, Kartasasmita CB. Pedoman Nasional Tuberkulosis pada Anak (2nd ed.). Jakarta: UKK Respirologi PP IDAI, 2005; p. 30-8.
13. Calonje JE, Brenn T, Lazar AJ, McKee PH. McKee's Histopatology of the Skin (4th ed.) Kanada: Elsevier, 2012; p. 81125.

14. Agrawal R, Kumar M, Kumar $\mathbf{P}$. Cutaneous tuberculosis, a clinicopathological study. Indian Journal of Medical Specialties. 2012;3(2):138-42.

15. World Health Organisation. Guidelines for the management of drug resistant tuberculosis. WHO/TB/96.210 (Rev.1). Geneva, 2007.

16. Setiabudy R. Golongan kuinolon dan florokuinolon. In: Gunawan SG, Setiabudy R, Nafrialdy, Elysabeth, editors. Farmakologi dan Terapi. Jakarta: Departemen Farmakologi dan Terapeutik Fakultas Kedokteran Universitas Indonesia, 2007; p. 718-22.

17. Yew WW. Newer fluoroquinolones for the treatment of tuberculosis. [cited 2014 Jun 5]. Available from: http://www.infectweb.com/only/02_Rev 1_DrWW_Yew.pdf. 